\title{
Application of Moiré technique on strain analysis in farm machinery elements $^{1}$
}

\author{
Aplicação da técnica de Moiré na análise de deformação em elementos de máquinas \\ agrícolas
}

\author{
Kelen Cristiane Cardoso ${ }^{2 *}$, Jonathan Gazzola² e Inacio Maria Dal Fabbro²
}

\begin{abstract}
Development and optimization of projects for agricultural machinery involve the analysis of stress and strain. Moiré photomechanical techniques provide a complete displacement field of the specimen under test, and can aid in understanding the mechanical behavior of parts with complex geometry. Hybrid methods combine fringe patterns of displacement with distribution maps of stress and strain through concepts of the theory of elasticity. The objective of this work was to analyse the use of the shadow moiré technique in the qualitative determination of stress and strain distribution in geometrically complex machine elements. The results were compared with those from an electrical extensometer and a computer simulation. The results demonstrated that the shadow moire technique was quite reliable in analysing the mechanical behavior of geometrically complex machine elements.
\end{abstract}

Key words: Photomechanical techniques. Hybrid methods. Shadow moiré.

RESUMO - Desenvolvimento e otimização de projetos de máquinas agrícolas envolvem a análise de tensão e deformação. Técnicas fotomecânicas de moiré fornecem campo de deslocamento completo do corpo de prova e podem auxiliar no entendimento do comportamento mecânico de peças com geometria complexa. Métodos híbridos associam franjas padrões de deslocamento com mapas de distribuição de tensão e deformação, através de conceitos de teoria da elasticidade. O objetivo deste trabalho foi analisar o uso da técnica de moiré de sombra para determinação qualitativa de distribuição de tensão e deformação em elementos de máquinas de geometria complexa. Os resultados foram comparados com o método de extensometria elétrica e por simulação computacional. Os resultados mostraram que a técnica de moiré de sombra foi bastante confiável para analisar o comportamento mecânico de elementos de máquinas de geometria complexa.

Palavra-chave: Máquinas Agrícolas. Técnicas Fotomecânicas. Moiré de sombra.

\footnotetext{
*Autor para correspondência

${ }^{1}$ Recebido para publicação em 19/04/2013; aprovado em 23/03/2014

Parte da Dissertação de Mestrado do primeiro autor apresentada ao curso de Pós-Graduação em Máquinas Agrícolas/Engenharia Agrícola da Universidade Estadual de Campinas

${ }^{2}$ Faculdade de Engenharia Agrícola, Universidade Estadual de Campinas, Campinas-SP, Brasil, 13.083-875, kelen.cardoso@feagri.unicamp.br, jonathan_gazzola@yahoo.com.br,inacio@feagri.unicamp.br
} 


\section{INTRODUCTION}

In agricultural science, mainly in farm machinery design and development, the association of stress and strain analysis to product optimization is of very common occurrence. Accurate analyses are based on isolated element tests through experimental techniques (MAZZETI FILHO et al., 2004). Strain-gage techniques generate point to point deformation and displacement data, requiring many sensors conveniently positioned which demands time and cost increase (RI; FUJIGAKI; MORIMOTO, 2010).

Mechanical components shapes are very commonly surveyed by means of optical techniques which can be associated to interferometry to generate solutions to problems involving static or dynamic situations (GOMES et al., 2009). Optical methods are usually named photomechanical techniques which are able to generate complete displacement field (ANDONIAN, 2008) being recognized as stress analysis experimental methods (LEI et al., 2007). Stress field can also be determined by means of hybrid methods which associate optical techniques with the theory of elasticity (DOYLE, 2008).

Moiré techniques are include in the photomechanical category which are based on optical interferometry, which yield excellent results in determining displacement field, however it requires adequate fringes spatial differentiation to generate stress and deformation fields. The advantages of moiré methods are associated to low cost of required equipment, low sensitivity to external noise, fast trials as well as and applicability to large displacement determination (DOYLE, 2008; GLEICE et al., 2011; RYU et al., 2008).

The moiré phenomenon takes place when two optical grids of certain density are superposed at a specific angle; fringes are generated with different period and angle of the two initial screens (LINO; DAL FABBRO, 2004). The third group of strips is denominated as moiré fringes which vary from dark color when generated by destructive interfering waves to totally clear color if generated by constructive interfering waves (BERALDO et al., 2007).

Moiré fringes can be generated by means of the shadow moiré or by the projection moiré method (PORTO; GURGEL; FARINATTI, 2011). In shadow moiré method, the grid is positioned in front of the testing body and illuminated by a light source, projecting the grid shade onto the object surface. Costa et al. (2008) recommend the application of that technique in deformation test, because that method generates more detailed fringes.

The application of moiré methods to photomechanical tests are based on the superposition of two sets of fringes generated on the loaded as well as on the unloaded testing body, respectively (XIAO et al., 2010). Image processing will generate the displacement field followed by the deformation and stress field (BASTOS; TAVARES, 2004).

The pertinent literature discloses several research reports on the application of moiré methods to determine the qualitative stress state on bodies of simple geometry. Mazzeti Filho et al. (2004) report the application of a moiré method to determine the displacement field on rubber discs models. Albiero et al. (2012) determined points of isodeformation on nuts shell surface. Gazzola et al. (2012) report qualitative determinations of stress distribution of wood beams under flexural loading.

The objective of this research work was to analyze the application of shadow moiré method to a qualitative determination of deformation and stress distribution on farm machinery elements of complex geometry.

\section{MATERIALS AND METHODS}

Photomechanical tests were carried out in the Laboratory of Optics of the Faculty of Agricultural Engineering at the State University of Campinas, in Campinas, SP, Brazil. A diaphragm spring taken from a tractor clutch was selected as testing body for exhibiting discontinuous as well as complex geometry associated to a working condition characterized by axial loading yielding out of plane displacement. Shadow moiré method was considered as a very adequate technique to determine the displacement fields on the above described situation. Experimental arrangement included a hydraulic testing press, a metal ring, an acrylic disc, a metal disc and a mechanical measuring gauge. The metal ring served as support to the testing body as well as to the acrylic disc, as it is displayed on Figure 1. The metal ring was used to transmit the load from the testing press to the diaphragm elements being positioned between the load cell and the diaphragm spring top. The displacement of the diaphragm spring elements was taken by the measuring gauge. Four diaphragm springs had been used in the experimental trials. Figure 2 displays the experimental setup conceived for loading tests.

Figure 1 - Metal ring cross sectional view as employed in the testing trials

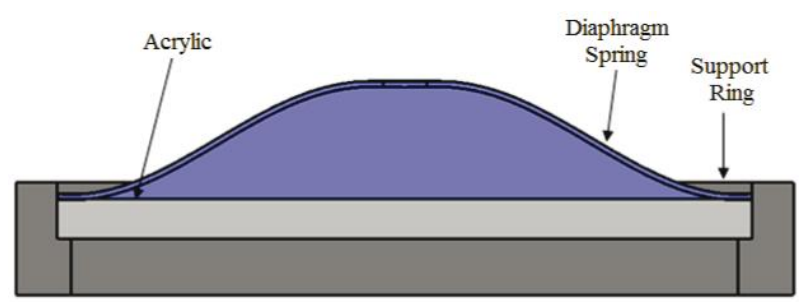


Figure 2 - Experimental setup for the diaphragm spring loading tests

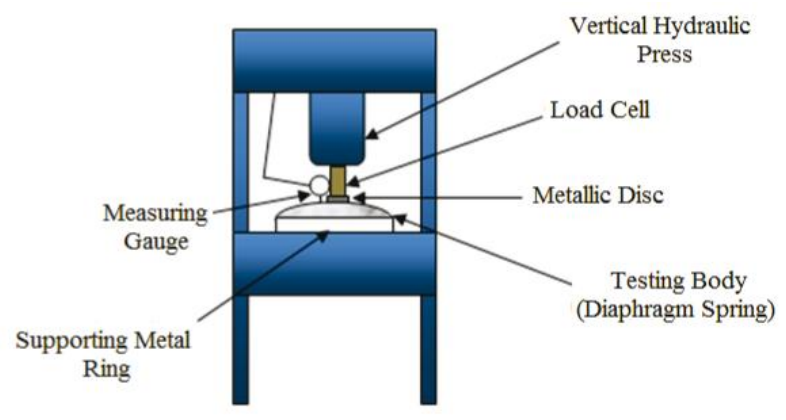

The experimental setup for the moiré photomechanical tests included a Ronchi optical grid with a period of $0.2 \mathrm{~mm}$, a SONY multimedia projector and a SAMSUNG digital camera of 6.1 Mega Pixels with remote control to prevent undesirable movement to capture images. Testing boby was painted with opaque White color to improve pattern fringes contrast. The optical grid was positioned in front of the testing body, as showed on Figure 3 (a) which details the moiré experimental setup. Figure 3 (b) exhibits the equipment positions during experimental trials.

It has been applied seven different force levels on the top of the diaphragm membrane generating up to $7 \mathrm{~mm}$ of axial displacement on the elements. First image was generated of non-deformed body following, one image at each $\mathrm{mm}$ of element displacement, generating a group of 8 images to be processed.
Image processing included the application of the IDRISI KILIMANJARO and ImageJ software which was divided into two steps, as it will be described as follows (GAZZOLA et al., 2010). In the first step a common processing was carried to all the images by means of the Image J software in order to remove the background from the testing body image, noise as well as filter application to improve fringes contrast as recommended by KUNINARI et al. (2008).

In the second step the isochromatic fringes map has been generated by means the IDRISI KILIMANJARO software, through the Whole field Subtraction Technique as described by Albiero et al. (2012) which is based on the pixel to pixel subtraction of na image generated at a Xi loading level from an image generated at $\mathrm{Xi}+1$ loading level. That method is employed to determine the undergoing deformation of a testing body between two different loading levels.

Following, the isochromatic fringes were identified from the pattern moiré fringes by means of the ImageJ software. Isochromatic fringes are understood as lines representing the differences between the principle stresses which are shown in different colors when the light source exhibits white pattern (SPINELLI; SILVA, 2003). Fringes also provide information on the regions exhibiting stress concentration from the displacement analysis. In that case the displacement at the point under analysis is inversely proportional to the fringes spacing, i.e., places with larger displacement will exhibit lower spacing among the fringes indicating a high stress

Figure 3 - (a) Experimental setup for shadow moiré tests and (b) equipment positioning

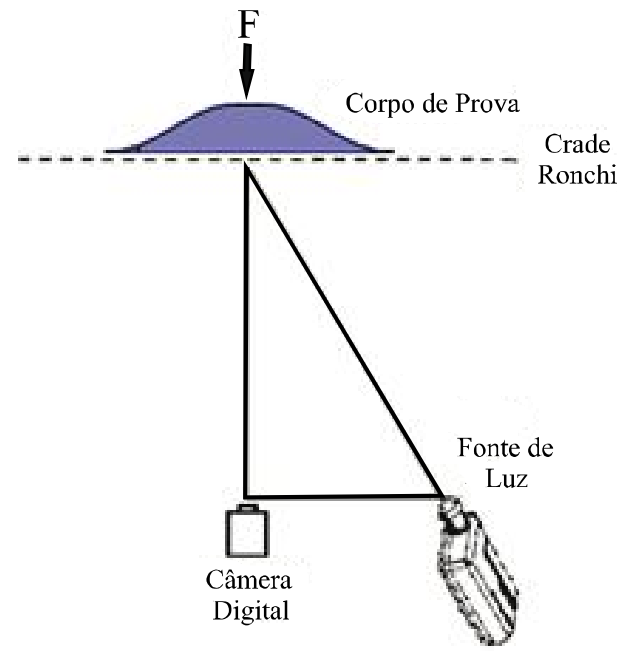

(a)

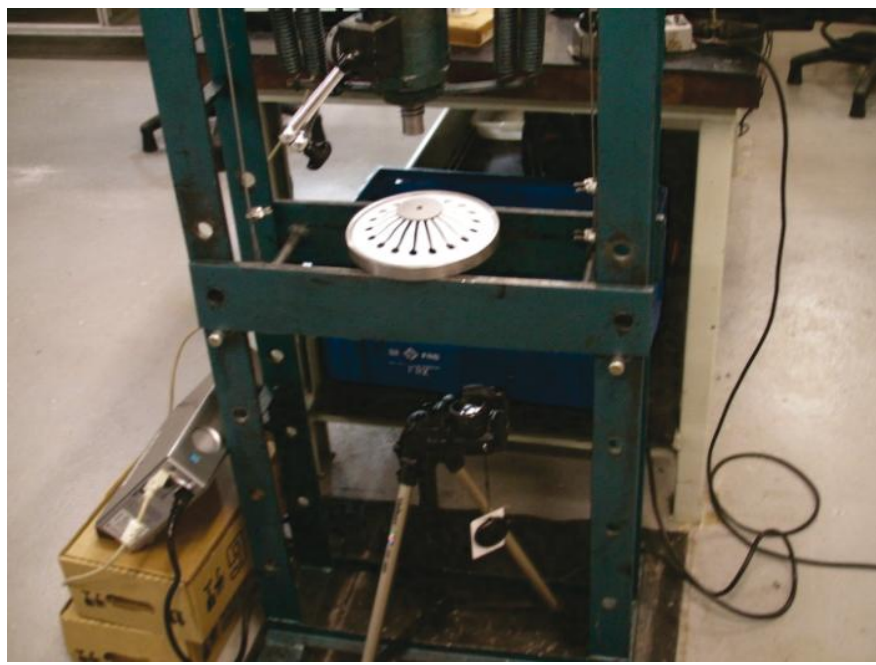

(b) 
concentration point (GAZZOLA et al., 2012). In order to compare as well as to validate the results generated by the moiré technique a finite element model was tested through the Abaqus 6.10 software. The simulation was carried on diaphragm spring element model holding the same dimensions as the real ones, where the virtual environment held the same load application conditions including imposed displacement and boundary conditions.

The next loading test was carried out to generate results through strain gage technique, i.e., by the application of extensometers, in which the extensometers were conveniently placed on the diaphragm elements in order to capture micro deformations. Two diaphragm elements had been tested. Figure 4 shows the strain gages positions set on the diaphragm elements, numbered from 1 to 5 on the top element meanwhile the lower element held the strain gages numbered from 6 to 10 .

Figure 4 - Strain gages positions on the diaphragm spring elements

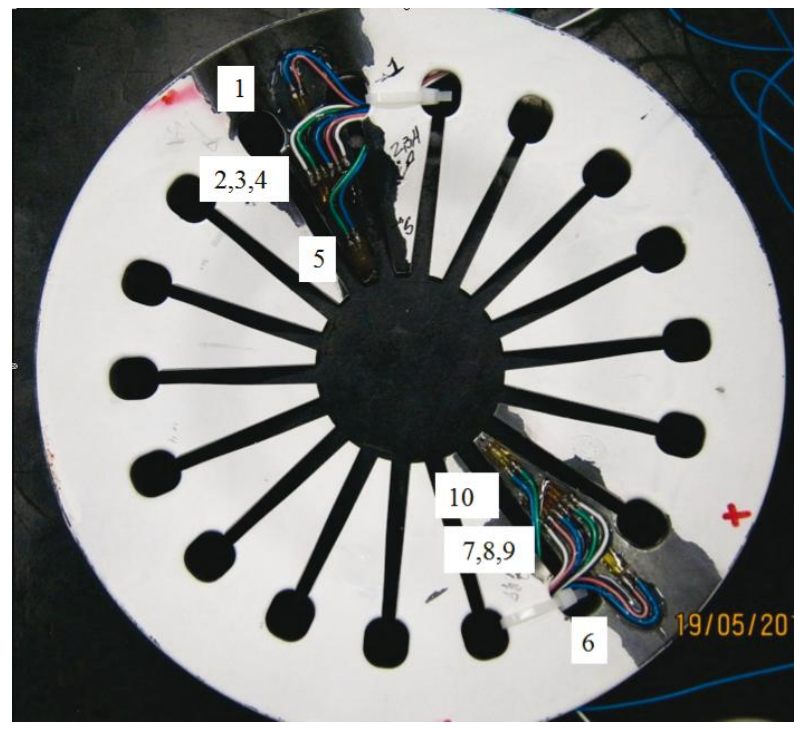

\section{RESULTS AND DISCUSSIONS}

Figure 5 shows an example of isodeformation map generated by the IDRISI KILIMANJARO software for each applied displacement and the resulting fringes subtraction corresponding to load and unloaded diaphragm elements and a scale associated to the pixel color intensity which is related to the element deformation. Table 1 shows the pixel light intensity for each trial.
Figure 5 - Isodeformation map generated by the IDRISI KILIMANJARO software

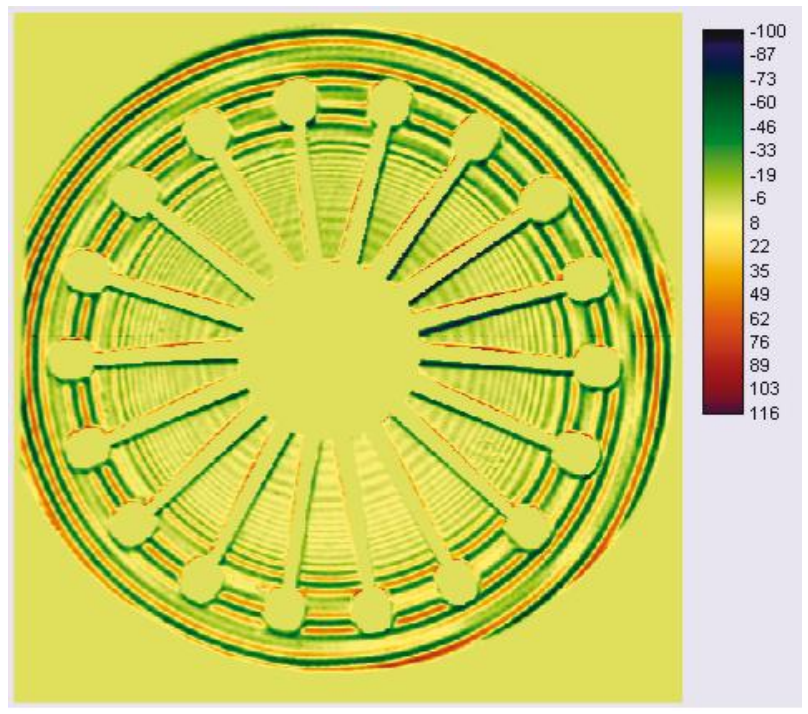

Table 1 - Pixel light intensity as generaterd by the IDRISI KILIMANJARO software

\begin{tabular}{lcccc}
\hline Displacement & Trial 1 & Trial 2 & Trial 3 & Trial 4 \\
\hline $1 \mathrm{~mm}$ & 116 & 166 & 201 & 165 \\
$2 \mathrm{~mm}$ & 138 & 199 & 209 & 197 \\
$3 \mathrm{~mm}$ & 154 & 217 & 226 & 214 \\
$4 \mathrm{~mm}$ & 176 & 240 & 224 & 233 \\
$5 \mathrm{~mm}$ & 190 & 251 & 239 & 249 \\
$6 \mathrm{~mm}$ & 204 & 261 & 254 & 258 \\
$7 \mathrm{~mm}$ & 216 & 265 & 267 & 268 \\
\hline
\end{tabular}

Figure 6, Figure 7, Figure 8 and Figure 9 shows the pixel intensity variation graph for each applied displacement.

The graphs show that the total pixel intensity variation presented linear behavior close to an average $\mathrm{R}^{2}$ value of $96 \%$ according to element deformation, i.e., when the diaphragm membrane is axially loaded which transmit a linear and direct deformation to the elements. A linear relation between the element deformation and pixel intensity is clearly noted.

Figure 10 exhibits the isochromatic lines map associated to each loading rate applied on the diaphragm spring top.

Figura 10 (a) shows a concentration of isochromatic fringes at the diaphragm border. As loading increased 
Figure 6 - Pixel intensity variation versus diaphragm element displacement graph for the trial 1

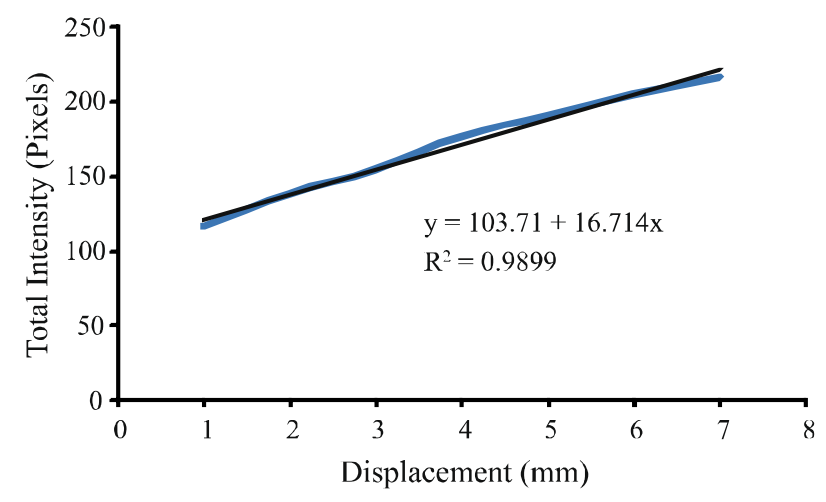

Figure 7 - Pixel intensity variation versus diaphragm element displacement graph for the trial 2

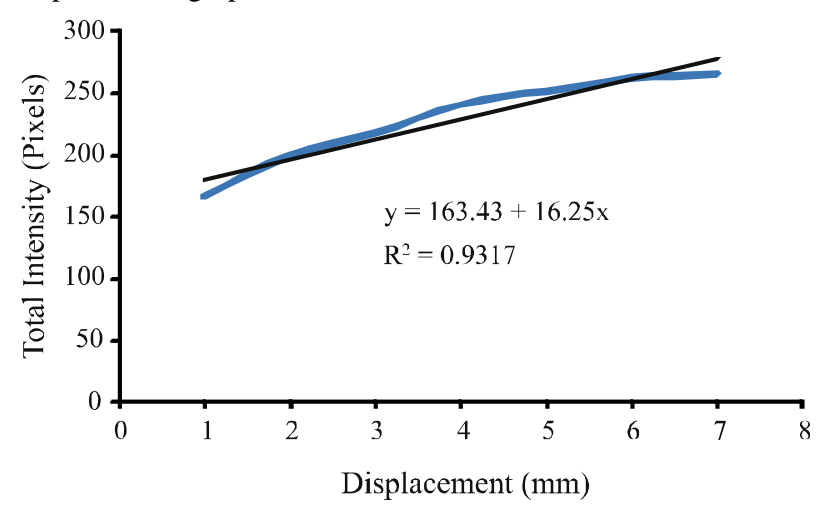

Figure 8 - Pixel intensity variation versus diaphragm element displacement graph for the trial 3

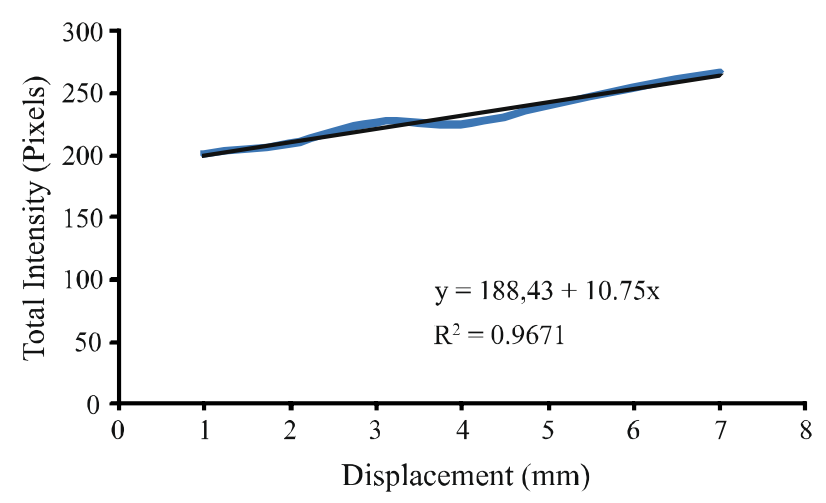

stress distribution covered the entire diaphragm surface, with visible fringes concentration. High concentration of lines clearly indicates stress concentration. Such fringes behavior indicates stress concentration evolution on the testing body due to the increasing loading. The fringe
Figure 9 - Pixel intensity variation versus diaphragm element displacement graph for the trial 4

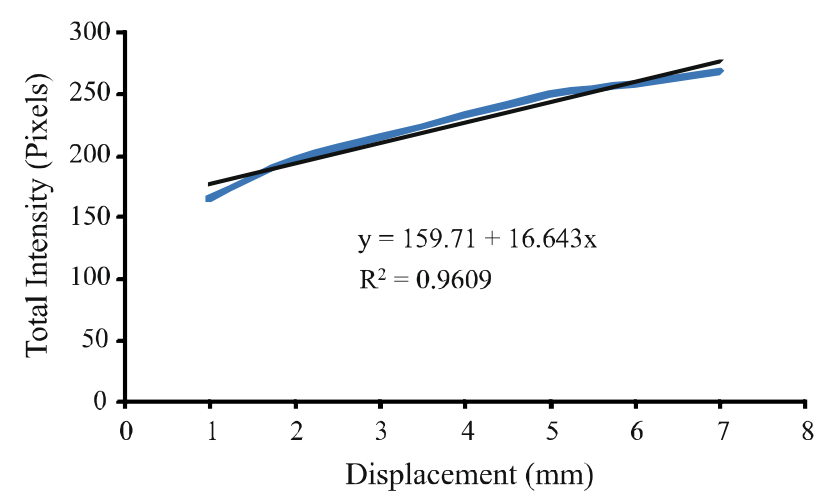

color intensity variation is associated to the imposed displacement variation, where the lowest displacement which is associated to the lowest stress is indicated predominantly by red color which progressively reaches the yellow color corresponding to the maximum imposed displacement of $7 \mathrm{~mm}$ which is, in turn, associated to the maximum stress. By comparing fringe distances it can be noted that the diaphragm elements located at the upper right side exhibits higher stress concentration at the borders and as the displacement increases, elements located at the bottom left side will show similar behavior. That fact indicates that the deformation rate of the diaphragm element is different.

Figure 11 shows stress evolution result on a diaphragm element generated by computer simulation for displacement variation from $1 \mathrm{~mm}$ to $7 \mathrm{~mm}$.

By analyzing Figure 11 it can be noted that the computer simulation indicates the higher stress concentration at the lateral region of the diaphragm spring, mainly at element basis as well as at diaphragm border. The central area of the diaphragm showed low stress concentration for the imposed displacement of $1 \mathrm{~mm}$, mainly between the diaphragm border and the element basis, where the stress values were close to zero. The imposed displacement of $7 \mathrm{~mm}$ did not show qualitative differences on the stress distribution map when compared with the displacement of $1 \mathrm{~mm}$, however the stress module was amplified. As the computer simulation map did not show qualitative differences on the stress distribution, remaining results were omitted, emphasizing that the stress modules are variables ranging from the maximum and minimum displacement.

Figure 12 compares the qualitative stress distribution as generated by the moiré method and the computer simulation associated to the displacement of $2 \mathrm{~mm}, 4 \mathrm{~mm}$ and $7 \mathrm{~mm}$. 
Figure 10 - Isochromatic lines map associated to displacement of (a) $1 \mathrm{~mm}$, (b) $2 \mathrm{~mm}$, (c) $3 \mathrm{~mm}$, (d) $4 \mathrm{~mm}$, (e) $5 \mathrm{~mm}$, (f) $6 \mathrm{~mm}$, (g) $7 \mathrm{~mm}$, and (h) color scale associated to pixel intensities as generated by the ImageJ software
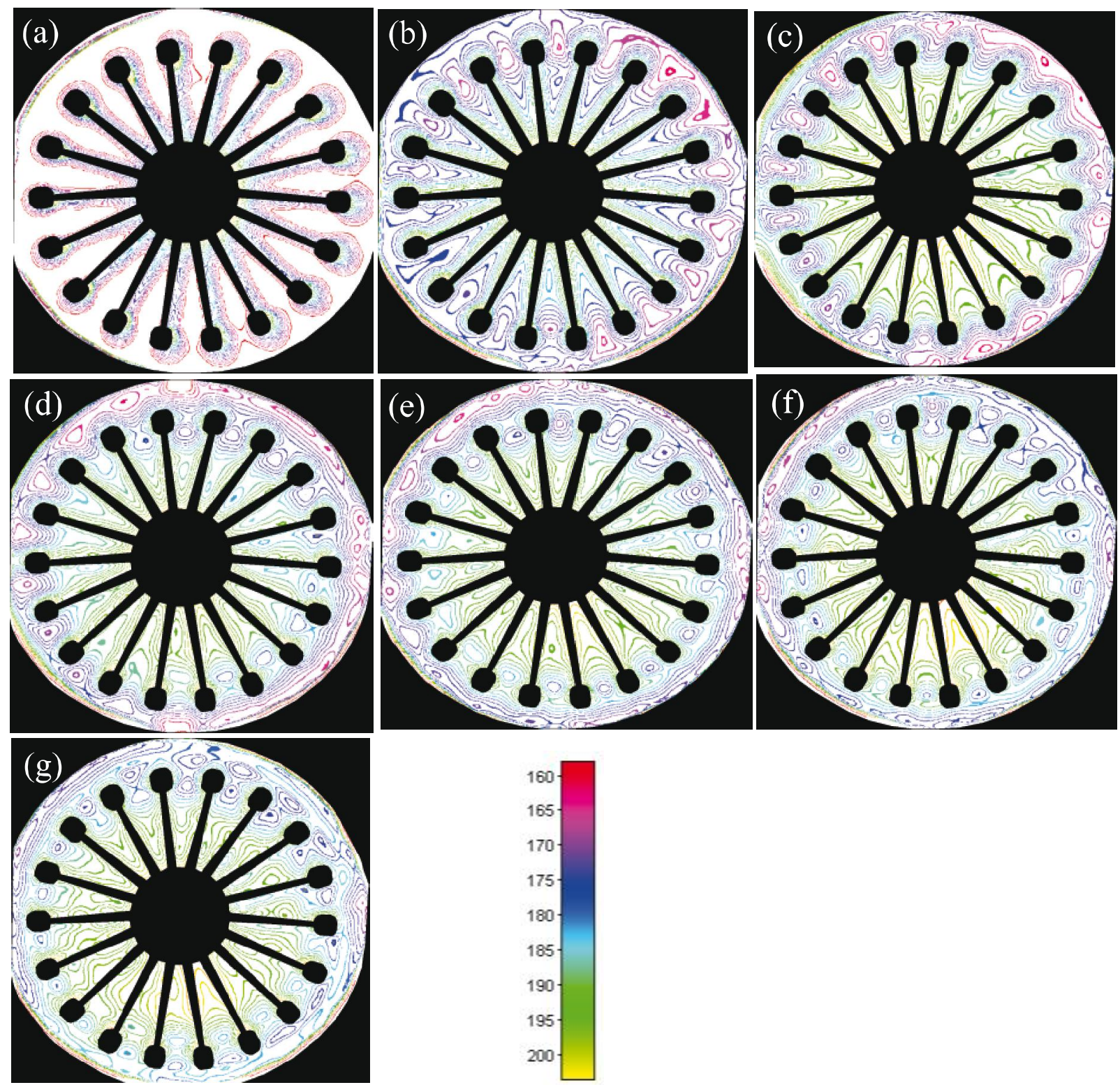

By comparing the figures displayed above it can be noted that stress distribution map as generated by the moiré method and by the computer simulation showed stress concentration at the element basis as well as on the diaphragm border. It is also noted that the low lines density coincides in both, moiré and computer simulation methods. It is also found close agreement between the moiré method and the computer simulation results referring to the regions of high stress intensity as the at the diaphragm border and the at the element basis. By the other side, moiré technique indicated concentration at the elements lateral areas where the analysis reveals high isochromatic fringes concentration. The qualitative results as generated by the computer simulation and by the moiré method differ, may be because the diaphragm industrial production did not maintain the same geometric pattern for all the elements. Some elements present certain irregularities associated to height and enclination. Quality control during production process aims to keep a pattern of maximum differentiation between element height and inclination. 
Figure 11 - Stress distribution maps as generated by the Abaqus software for displacements of (a) $1 \mathrm{~mm}$ and (b) $7 \mathrm{~mm}$

\begin{tabular}{|c|}
\hline $\begin{array}{l}\text { S, Mises } \\
\text { (Avg: } 100 \%) \\
\begin{aligned} & +1.157 \mathrm{e}+02 \\
& +1.109 \mathrm{e}+02 \\
& +1.061 \mathrm{e}+02 \\
& +1.013 \mathrm{e}+02 \\
& +9.650 \mathrm{e}+01 \\
& +9.172 \mathrm{e}+01 \\
& +8.693 \mathrm{e}+01 \\
& +8.214 \mathrm{e}+01 \\
& +7.735 \mathrm{e}+01 \\
& +7.257 \mathrm{e}+01 \\
& +6.778 \mathrm{e}+01 \\
& +6.299 \mathrm{e}+01 \\
& +5.820 \mathrm{e}+01 \\
& +5.342 \mathrm{e}+01 \\
& +4.863 \mathrm{e}+01 \\
& +4.384 \mathrm{e}+01 \\
& +3.905 \mathrm{e}+01 \\
& +3.427 \mathrm{e}+01 \\
& +2.948 \mathrm{e}+01 \\
& +2.469 \mathrm{e}+01 \\
& +1.990 \mathrm{e}+01 \\
& +1.512 \mathrm{e}+01 \\
& +1.033 \mathrm{e}+01 \\
& +5.543 \mathrm{e}+00 \\
& +7.550 \mathrm{e}-01\end{aligned}\end{array}$ \\
\hline
\end{tabular}

(a)

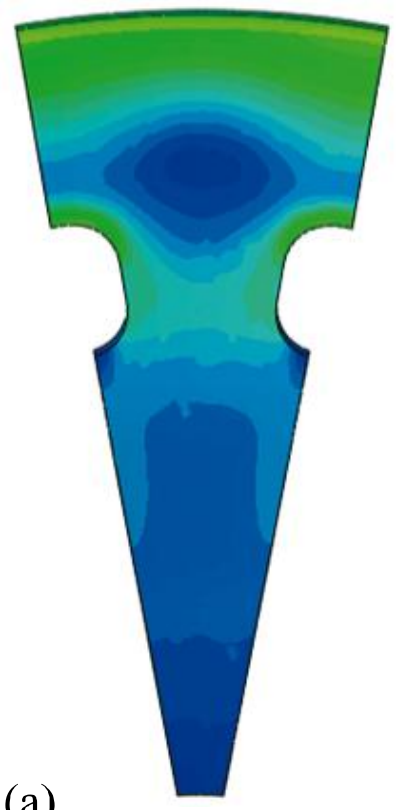

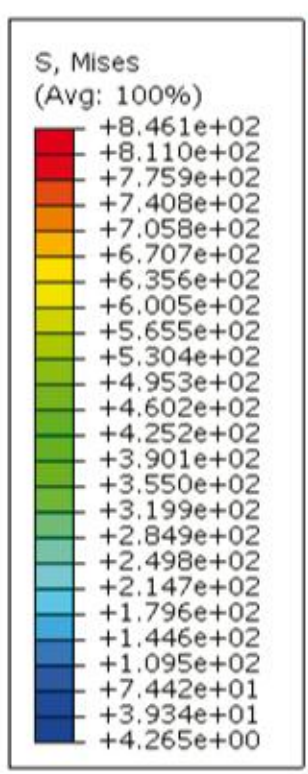

(b)

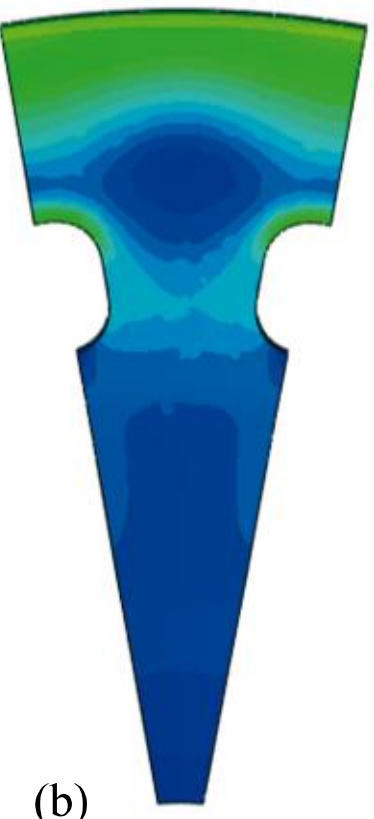

Figure 12 - Comparisson of the stress distribution results generated by the moiré method and the computer simulation for displacement imposition of (a) $2 \mathrm{~mm}$, (b) $4 \mathrm{~mm}$ and (c) $7 \mathrm{~mm}$
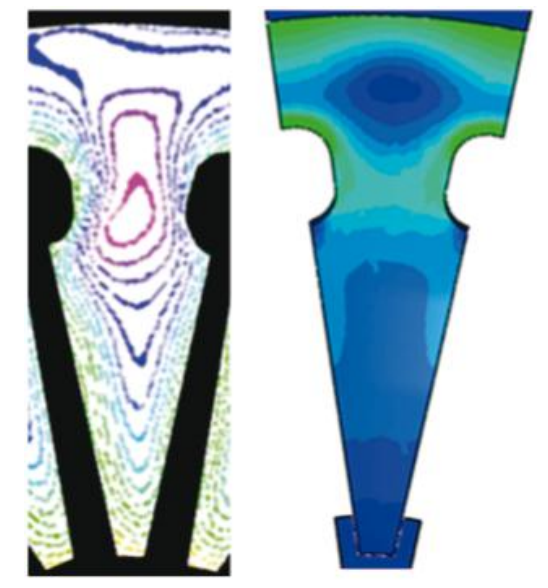

(a)

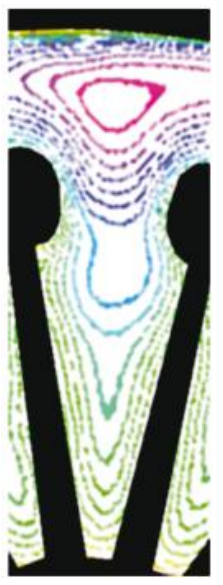

(b)

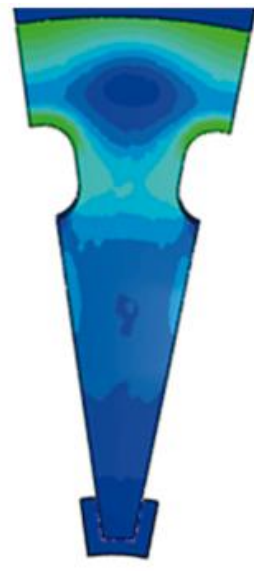

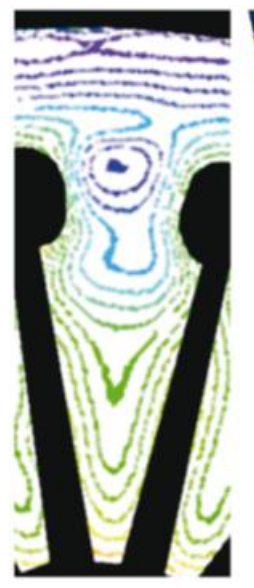

(c)

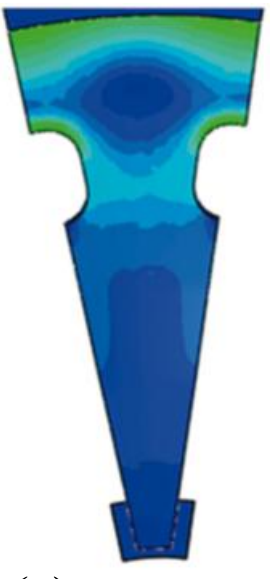

However, such a geometrical differentiation generates certain variations on the stress distribution during loading. That hypothesis was verified by means of the extensometric technique.

Figure 13 shows the results yielded by means of the extensometric technique.

Results obtained as shown on the graph indicate that at each displacement applied on the testing body, an irregular deformation increment, i.e., the elements showed, each one, different deformation rates.
The graph displayed on figure 13 indicate that the resulting stress generated by extensometry show similar qualitative behavior as the deformation variation between the elements when generated by the moiré method. This confirms that the stress and deformation variation between elements of a diaphragm spring is a recurrent situation and it must be considered in designs.

Generaly speaking, resulting stress distribution generated by the moiré method indicates that stress concentrates initially at the diaphragm border. It was 
Figure 13 - Strain gage graph output respectively for the positions (a) 1 and 6, (b) 2 and (7), (c) 3 and 8, (d) 4 and 9, (e) 5 and 10

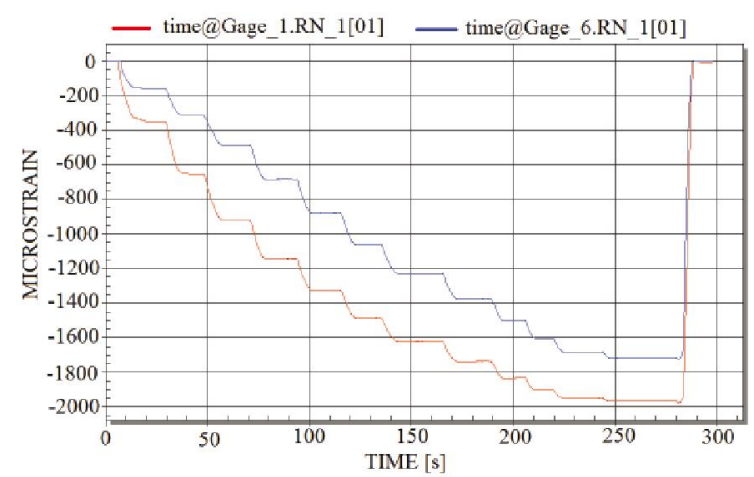

(a)

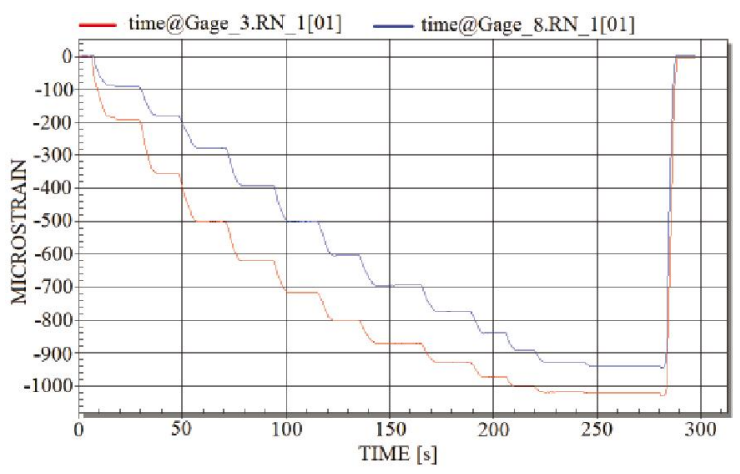

(c)

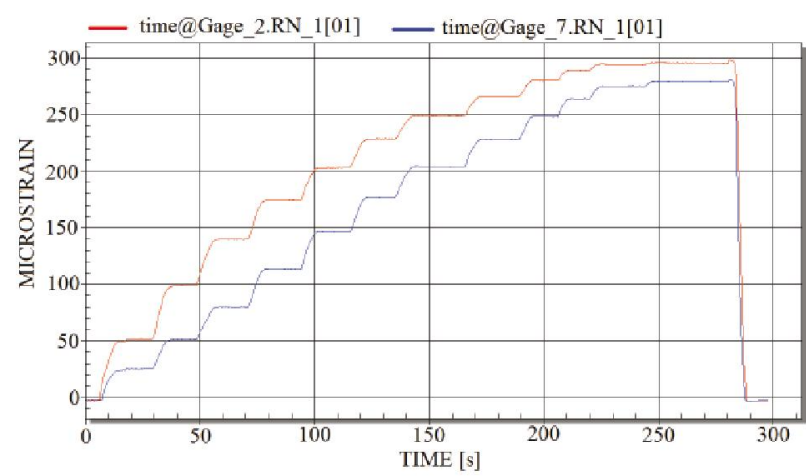

(b)

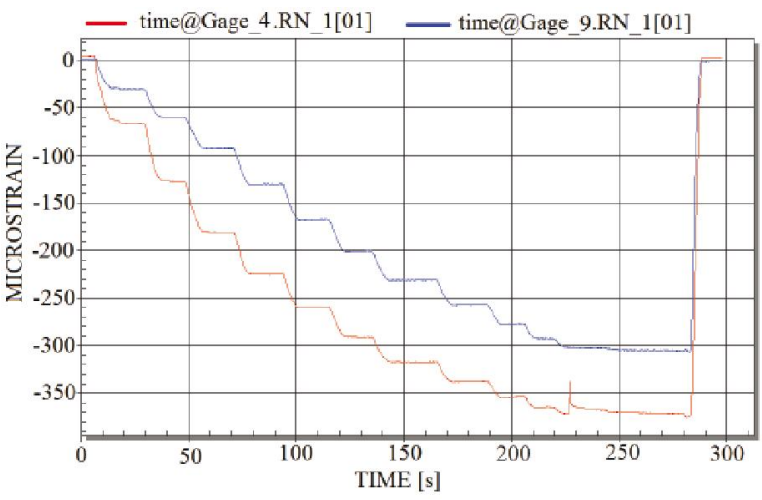

(d)

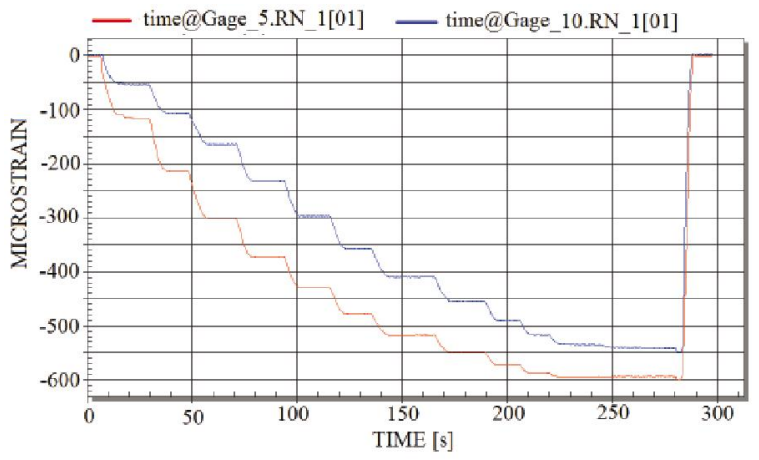

(e)

also revealed stress concentration at the element border as well as at the element basis. The element displacement increased with the stress module. Stress distribution showed no symmetry among the elements of the diaphragm membrane. The isochromatic fringes evolution related to pixel color intensity, position and distance, revelead the stress distribution dynamics on the diaphragm spring. Pixel intensity analysis show, in a qualitative way, the stress increase on the testing body.

Obtained results from computer simulation showed that stress module experienced an increment as the displacement was augmented. Stress concentration was located at element basis as well as at the diaphragm border.

Results as obtained by extensometry showed some irregularities on element deformation, which is in close agreement with the results obtained by the moiré method. The hypothesis raised on the element geometric irregularities can be confirmed, since the loading test as imposed to the diaphragm spring are in close agreement.

The discrepancies showed by the computer model is based on the assumption of material isotropicity, 
continuity as well as regularity, which are not assumed by the extensometry, nor by the moiré method. In other words, moiré and extensometry assume the body to exhibit real behavior.

The absence of variation on elements deformation results indicated by computational simulation has been occurred because this technique analyzes parts characterized to be isotropic, homogeneous, continuous and unique geometry between elements. But, moiré and extensometric techniques, which demonstrated such variations, results have been generated on testing body with geometry variation between elements and material irregularities.

\section{CONCLUSION}

Based on what it has been explained before, it can be concluded that the shadow moiré technique can be considered as a profile measuring method of mechanical analysis which can generate reliable results in determining qualitative stress distribution on machine elements of complex geometry. Results generated by the shadow moiré method corresponded to the expected results as obtained by extensometry. The simplicity showed by the above referred method turn it attractive to the experimental mechanics study as well as to industrial applications. Stress and deformation quantification studies are recommended for future studies.

\section{REFERENCES}

ALBIERO, D. et al. Moiré Optical Technique For Evaluation Of Cashew Nuts (Anacardium Occidentale, L.) Isostrain. Varia Scientia Agrarias, v. 2, n. 2, p. 9-20, 2012.

ANDONIAN, A. A. T. Optical Methods. Springer Handbook of Solid Mechanics. New York: Sharpe, 2008. p. 823-837.

BASTOS, L. F.; TAVARES, J. M. R. S. Um sistema de ferramentas de processamento e análise de imagens de moiré: apresentação. In: ENCONTRO NACIONAL DE ANÁLISE DE TENSÕES E MECÂNICA EXPERIMENTAL, 5., 2004, Coimbra. Anais... Coimbra: APAET, 2004.

BERALDO, A. L. et al. Técnica de moiré aplicada al análisis de esfuerzos de compresión en el bambu guadua. Maderas: Ciencia y Tecnologia Concepción, v. 9, n. 3, p. 309-322, 2007.

BRAGA, R. A. et al. Supression of border effects in moiré techniques using three-dimensional methods. Biosystems Engineering, v. 102, n. 1, p. 1-8, 2009.
COSTA, R. M. et al. Sensitivity of the moiré technique for measuring biological surfaces. Byosistem Engineering, v. 100, n. 3, p. 321-328, 2008.

DOYLE, J. F. Hybrid Methods. Springer Handbook of Solid Mechanics. New York: Sharpe, 2008.

GAZZOLA, J. et al. Shadow Moiré Applied to Torsional Stress Distribution Mapping. Agricultural Engineering Journal, v. 48, n. 2, p. 61-65, 2010.

GAZZOLA, J. et al. Photomechanical analysis of wooden testing bodies under flexural loadings. World Academy of Science, Engineering and Technology, v. 70, p. 396-401, 2012.

GOMES, T. S. et al. Calibração da técnica de moiré aplicada a perfilometria de protótipos mecânicos. Revistas Ciência e Agrotecnologia, v. 33, n. 2, p. 574-579, 2009.

GLEICE, C. A. et al. Recuperação de Topografia de Ovos por Meio da Técnica de Moiré e Calibração Independente. Engenharia Agrícola. v. 31, n. 2, p. 211-218, 2011.

KUNINARI, F. et al. Moiré aided soil-tractor tire contact area and contact volume determination. Journal of Agricultural Machinery Science, v. 4, n. 1, p. 39-43, 2008.

LEI, Z.; YUN, H.; YUN, D.; KANG, Y. Numerical analysis of phase-stepping interferometric photoelasticity for plane stress separation. Optics ans Laser in Engineering, v. 45, n. 1, p. 77-82, 2007.

LINO, A. C. L.; DAL FABBRO, I. M. Determinação da topografia de uma fruta pelas técnicas de moiré de sombra com multiplicação de franjas. Revista Ciência Agrotécnica. v. 28 , n. 1 , p. 119-125, 2004.

MAZZETI FILHO, V. et al. Application of a Moiré technique in the stress distribution mapping of circular rotors. Revista Ciência e Tecnologia, ano 7, n. 10, p. 31-34, 2004.

PORTO, F.; GURGEL, J. L.; FARINATTI, P, T, V. Topografia de Moiré como Método de Avaliação Postural: Revisão do Estado da Arte. Revista Brasileira de Geriatria e Gerontologia, v. 3, n. 14, p. 567-577, 2011.

RI, S.; FUJIGAKI, M.; MORIMOTO, Y. Sampling Moiré Method for Accurate Small Deformation Distribution Measurement. Experimental Mechanics. v. 50, n. 4, p. 501-508, 2010.

RYU, W. et al. A Study on the 3-D Measurement by Using Digital Projection Moiré Method. Optik - International Journal for Light and Eletron Optics. v. 119, n. 10, p. 453458, 2008.

SPINELLI, H. A.; SILVA, F. A. Aplicação da Fotoelasticidade na Análise Estrutural de uma Junta Rebitada de Uso Aeronáutico. 2003, Guaratinguetá. Anais... Guaratinguetá, 2003.

XIAO, X. et al. Displacement and Strain Measurement by Circular and Radial Gratings Moiré Method. Experimental Mechanics, v. 50, n. 2, p. 239-244, 2010. 